\title{
Influence of Carbohydrates on Callus Proliferation During Somatic Embryogenesis in Pineapple [Ananas Comosus (L.) Merr. (Bromeliaceae) Var. Cayenne Smooth Cultivar CI 16]
}

\author{
Kouadio Oi Kouadio Samuel \\ Université Nangui Abrogoua, UFR des Sciences de la Nature, \\ Laboratoire de Biologie et Amélioration des Productions Végétales, \\ Abidjan 02, Cote d'Ivoire \\ Yapo Edwige Sopie Salomé
}

Université Jean Lorougnon Guédé, UFR Agroforesterie, Laboratoire de

Physiologie et Pathologie Végétale, Daloa, Côte d'Ivoire

\section{Silue Oumar}

Centre National de Recherche Agronomique (CNRA),

Laboratoire Central de Biotechnologie, Abidjan, Côte d'Ivoire

\section{Adou Bini Yao Christophe \\ Kouakou Tanoh Hilaire}

Université Nangui Abrogoua, UFR des Sciences de la Nature,

Laboratoire de Biologie et Amélioration des Productions Végétales,

Abidjan 02, Côte d'Ivoire

Doi: 10.19044/esj.2018.v14n15p287 URL:http://dx.doi.org/10.19044/esj.2018.v14n15p287

\section{Abstract}

The improvement of pineapple (Ananas comosus var. Smooth Cayenne) by means of in vitro culture is less studied in Côte d'Ivoire despite the importance of this plant for this country's economy. Our work consisted in highlighting nature and concentration effects of carbohydrates on the proliferation of calli in pineapple as a prelude to efficient embryogenesis. Callus proliferation was carried out from the base of pineapple vitroplants leaves. Thirty (30) explants were cultured on the tested culture medium. MS medium (micro- and macro elements of Murashige and Skoog) supplemented with vitamin Gamborg $\mathrm{B}_{5}$ was used as base medium to which were added 0.05 $\mathrm{mg} / \mathrm{L}$ BAP, $3 \mathrm{mg} / \mathrm{L}$ picloram, $2 \mathrm{mg} / \mathrm{L}$ glycine, $1,000 \mathrm{mg} / \mathrm{L}$ glutamine, 100 $\mathrm{mg} / \mathrm{L}$ casein hydrolyzate and $30 \mathrm{~g} / \mathrm{L}$ carbohydrate. Sucrose was tested at different concentrations $(20,25,30,35$ and $40 \mathrm{~g} / \mathrm{L})$. The results revealed that callus proliferation is strongly influenced $(p<0.0001)$ by nature and concentration of carbohydrate. Sucrose with the highest dry matter content 
(61.34 mg) has a higher callogenic potential than the other studied carbohydrates. The concentration of $30 \mathrm{~g} / \mathrm{L}$ sucrose significantly improved the calli proliferation in pineapple. Galactose and maltose were less favorable to proliferation.

Keywords: Pineapple, embryogenesis, in vitro culture, carbohydrate, sucrose

\section{Introduction}

In Côte d'Ivoire, the agricultural sector occupies a prominent place in the national economy. It represents $33 \%$ of the current GDP and was at the origin of the "Ivorian economic miracle" of the years 1970-1980 (Anonymous 1, 2008). This economic boom was made possible due to a special agricultural policy in favor of the coffee-cocoa binomial. Today, with regard to the international price cuts of those main export products, it is necessary to proceed to the diversification of crops to ensure the economic stability of this country whose economy is mainly based on agriculture. The culture of pineapple (Ananas comosus var. Cayenne smooth) was part of this policy of crop diversification. Indeed, it has occupied an important place in the Ivorian economy $(0.6 \%$ of the national GDP and $1.6 \%$ of the agricultural GDP) (OCAB, 2000; Adomon, 2007; MINAGR, 2013). The couple pineapple banana has therefore generated an annual turnover of 145 billion FCFA (Nouza, 2011). It is not only a source of employment but also an important source of foreign exchange earnings. For more than a decade, Côte d'Ivoire was the leading supplier of fresh pineapple in the European market (97\%). Today, this sector is affected by many problems that consequently led to a sudden drop in production, about $90.4 \%$ in 2014 as compared the production in 1999 (Anonymous 2, 2015). To these problems one should add the issue of the acidity and aging of the orchard (Tanoh, 2008). The economic importance of pineapple crop for Côte d'Ivoire triggered us in giving a high worth study priority in order to find solutions to the problems that undermine this sector. Thus, to renew the orchard and clean up the fruit, several cultivation methods were used without real success. However, biotechnology that covers many fields ranging from tissue culture concepts, genetic engineering to biotechnology applications could be an interesting tool. Several in vitro pineapple regeneration tests were carried out (Firoozabady and Gutterson, 2003; Be and Debergh, 2006; Danso et al., 2008; Yapo et al., 2011). The culture media developed during this work very often include sugars as sources of carbon. Indeed, since in vitro tissues are generally heterotrophic due to the absence of chlorophyll assimilation, it is necessary to provide them with a carbon source. Moreover, that carbon source becomes a sort of energy, necessary for tissue growth and maintains an osmotic pressure of the culture medium (Zryd, 1988). Carbohydrates most commonly used as a source of 
carbon are sucrose and glucose (Walker and Parrott, 2001). Maltose may be a good carbon source, since it can improve both the quality and quantity of somatic embryos produced (Saadi, 1991) in some studies of embryogenesis. The effects of other carbohydrates have been tested during the embryogenesis of several species (Unnikrishnan et al., 1990; Tremblay and Tremblay, 1995; Kouakou, 1996; Zouzou et al., 1997; N'cho, 2006). However, for calli proliferation, the results obtained differ from one sugar to another (Najiba et al., 2008). Our objective in this study is to identify the carbohydrate and its appropriate concentration to the proliferation of callus in the pineapple (Ananas comosus var. Smooth Cayenne), cultivar CI 16. Thus, six carbohydrates (sucrose, glucose, maltose, mannitol, fructose and galactose) were tested. The choice of these carbohydrates is motivated by the work done by Najiba et al. (2008) on the embryogenesis of Olea europaea. After selecting the best carbon source, its optimal concentration was identified.

\section{Material and methods}

\section{Plant material}

In this study, the leaves of young shoots obtained in vitro from pineapple (Ananas comosus var. Smooth Cayenne, cv. CI 16) suckers were used as plant material. They were harvested from the plantations of CNRA's production station in Anguédédou (Côte d'Ivoire, West Africa) to be carried out at CNRA's central biotechnology laboratory in Abidjan (Côte d'Ivoire).

\section{Methods}

\section{Callus induction}

Callus induction was performed on MS basal medium (Murashige and Skoog, 1962) containing Gamborg vitamin $\mathrm{B}_{5}$, supplemented with picloram (3 mg/L), glycine (2 mg/L), glutamine $(1,000 \mathrm{mg} / \mathrm{L})$, casein hydrolyzate $(100$ $\mathrm{mg} / \mathrm{L})$ and sucrose $(30 \mathrm{~g} / \mathrm{L})$. The $\mathrm{pH}$ of the culture medium was adjusted to 5.5 with $\mathrm{NaOH}(1 \mathrm{~N})$ or $\mathrm{HCl}(1 \mathrm{~N})$. The culture medium was solidify with $6 \mathrm{~g} / \mathrm{L}$ of Agar-agar, then sterilized by autoclaving (Autester) for $30 \mathrm{~min}$ at $121{ }^{\circ} \mathrm{C}$, under a pressure of 1 bar. After solidification of the culture medium, under a hood, about 5 to $7 \mathrm{~mm}$ from the base of the shoots leaves were cut and then deposited on the callus induction medium at the rate of five explants per jar. The jars containing the explants are placed in the culture room for four weeks. The calli obtained served as an explant for the study of calli proliferation.

\section{Effect of carbon sources on callus proliferation Preparation of the medium}

The MS medium (Murashige and Skoog, 1962) was used as basic medium in this study. This medium was used by several authors (Akbar et al., 200; Ika and Ika, 2003; Yapo et al., 2011) for calli induction in pineapple. It 
includes macroelements and microelements (Murashige and Skoog, 1962), added Gamborg $\mathrm{B}_{5}$ vitamin, supplemented by $0.05 \mathrm{mg} / \mathrm{L}$ BAP, $3 \mathrm{mg} / \mathrm{L}$ picloram, $2 \mathrm{mg} / \mathrm{L}$ glycine, $1,000 \mathrm{mg} / \mathrm{L}$ glutamine, $100 \mathrm{mg} / \mathrm{L}$ casein hydrolyzate. These concentrations were chosen according to callus induction method (Yapo et al., 2011). All culture media have the same composition of mineral elements with the exception of carbohydrate which is the specific element of each medium. The different media were named according to the carbon source used. Thus, carbohydrates such as sucrose; Glucose; Maltose; Mannitol; Fructose and galactose designate the culture media which respectively contain those carbon sources. The media were solidified with 6 $\mathrm{g} / \mathrm{L}$ agar-agar and $0.75 \mathrm{~g} / \mathrm{L}$ magnesium chloride. The $\mathrm{pH}$ of calli proliferation media was adjusted to 5.5. The culture media were sterilized in an autoclave (Autester) during $30 \mathrm{~min}$ at $121^{\circ} \mathrm{C}$, under one barof pressure.

\section{Callus proliferation and culture conditions}

Friable and non-brown calli obtained from calli induction phase were weighed. Then, approximately $10 \mathrm{mg}$ of these calli were seeded on to the culture medium at a rate of two cals per jar. The jars containing $10 \mathrm{~mL}$ of callus proliferation media were placed in a controlled culture room of $20 \mathrm{~m}^{2}$ according to the conditions identified above for 6 weeks. Thirty (30) explants were cultured on each tested medium. Each medium is repeated 15 times. A repeat consists of a jar of 2 explants. The best carbohydrate identified in this study is used for further testing.

\section{Effect of sucrose concentration on callus proliferation}

The aim of this study is to determine the best concentration of sucrose identified in the previous study as the adequate carbohydrate for callus growth in pineapple. For this purpose, only the concentration of sucrose varies; those of other components of these media being already known. In this study, different concentrations of sucrose $(20,25,30,35$ and $40 \mathrm{~g} / \mathrm{L})$ were tested. As in the previous study, under a laminar flow hood, about $10 \mathrm{mg}$ of healthy and friable calli were and seeded on the proliferation culture medium. Thirty (30) explants were used on each of these media. Each medium tested is repeated 15 times. A repeat consists of a jar of two explants. The jars containing the mediaseeded explants were randomly placed in a culture chamber under the same conditions as in the previous experiments. After 6 weeks, the dry weight of the calli which best expresses the quantity of material produced, was evaluated.

\section{Statistical analysis}

Statistical analysis were carried out through one-way ANOVA using General Linear Model procedure in Statistica 7.1 software and standard 
deviation for each mean was worked out. In case of a significant difference between averages in a given parameter, Newman Keuls comparison test is used at $p \leq 0.05$ for averages classification. This enabled us to identify variables (fresh weight and dry weight) for which there is a significant difference between the tested parameters (nature and content of carbon source).

\section{Results}

\section{Effect of carbohydrate nature on callus proliferation}

After six weeks of culture, the evaluation of callus proliferation on the six studied media showed a difference in the intensity of callus proliferation according to the used carbon source (Figure 1). The fresh weight of the calli was significantly influenced by the carbon source $(p<0.0001)$. These results revealed that glucose induced the highest fresh material weight $(106.1 \mathrm{mg})$ followed by mannitol $(103.41 \mathrm{mg})$ and sucrose $(101.07 \mathrm{mg})$, which were not significantly different, then maltose $(73.17 \mathrm{mg})$; galactose $(73.53 \mathrm{mg})$ and finally fructose $(70.21 \mathrm{mg})$ (Table 1). Statistical analysis also revealed that dry weight was very significantly influenced by the carbon source $(p<0.0001)$. Unlike the fresh weight of calli, the largest dry matter weight $(61.34 \mathrm{mg})$ was obtained with sucrose. The other types of sugar had statistically identical mean dry matter weights. All carbon sources resulted in greenish-colored calli with the exception of galactose and mannitol, which produced brown calli.

From these observations, it appears that the sucrose which enabled us to obtain the highest amount of dry matter is the most favorable carbon source for callus proliferation in pineapple. The dry matter weight of the calluses, having made it possible to assess the quantity of cells formed, will therefore be used for the rest of the work.

Table 1. Evaluation of carbon source effect on callus proliferation in pineapple

\begin{tabular}{llll}
\hline \multirow{2}{*}{$\begin{array}{l}\text { Nature of carbon source } \\
(30 \mathrm{~g} / \mathrm{L})\end{array}$} & $\begin{array}{l}\text { Presh weight } \\
(\mathrm{mg} \pm \mathrm{s})\end{array}$ & $\begin{array}{l}\text { Dry weight } \\
(\mathrm{mg} \pm \mathrm{s})\end{array}$ & Color \\
\hline Glucose & $106,1 \pm 3,54 \mathrm{a}$ & $16,61 \pm 2,35 \mathrm{~b}$ & greenish \\
Sucrose & $103,07 \pm 5,12 \mathrm{ab}$ & $61,34 \pm 5,73 \mathrm{a}$ & greenish \\
Mannitol & $101,41 \pm 4,51 \mathrm{ab}$ & $11,23 \pm 3,58 \mathrm{~b}$ & greenish \\
Galactose & $73,53 \pm 2,35 \mathrm{~b}$ & $17,17 \pm 2,01 \mathrm{~b}$ & brownish \\
Maltose & $73,17 \pm 5,12 \mathrm{~b}$ & $11,7 \pm 3,49 \mathrm{~b}$ & brownish \\
Fructose & $70,21 \pm 2,32 \mathrm{c}$ & $19,25 \pm 0,34 \mathrm{~b}$ & greenish \\
\hline
\end{tabular}

\section{Effect of sucrose concentrations on callus proliferation}

The results of sucrose concentrations effect on callus proliferation are shown in Figure 2. The proliferation of calli was very significantly affected $(p<0.0001)$ by the concentration of sucrose. Indeed, the dry weight of calli increases from 26 to $93 \mathrm{mg}$ for sucrose concentrations ranging from 20 to 30 
$\mathrm{g} / \mathrm{L}$ and then decreases sharply (from 93 to $31 \mathrm{mg}$ ) for concentrations above $30 \mathrm{~g} / \mathrm{L}$. These results revealed that sucrose at $30 \mathrm{~g} / \mathrm{L}$ induced the formation of the largest amount of dry matter $(93 \mathrm{mg})$, followed by $25 \mathrm{~g} / \mathrm{L}(62 \mathrm{mg})$ and 35 $\mathrm{g} / \mathrm{L}(58 \mathrm{mg})$. These sucrose contents $(25$ and $35 \mathrm{~g} / \mathrm{L})$ induced statistically identical amounts of dry matter (respectively 62 and $58 \mathrm{mg}$ ). The concentrations 20 and $40 \mathrm{~g} / \mathrm{L}$ obtained the lowest amounts of dry matter (respectively 26 and $31 \mathrm{mg}$ ).

This study makes us identify the sucrose concentration of $30 \mathrm{~g} / \mathrm{L}$ as the optimal concentration for a good calli proliferation in pineapple, as a prelude to efficient embryogenesis.

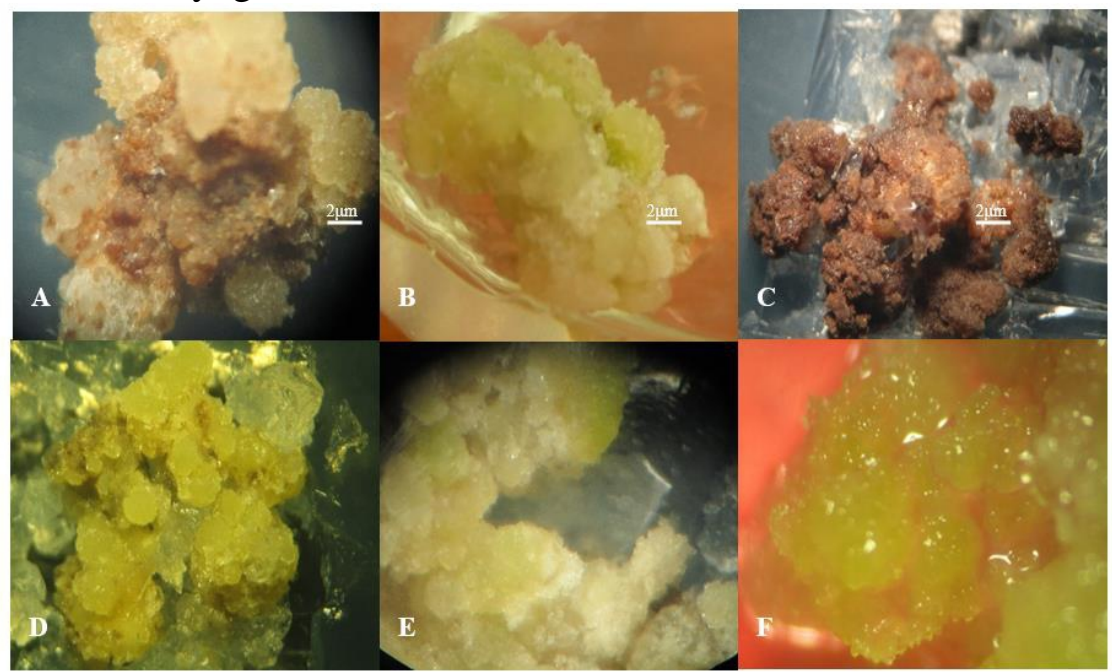

Figure 1. Proliferated pineapple calli on MSB5 medium containing different sources

Of carbon at $30 \mathrm{~g} / \mathrm{L}$.

(A) Galactose: Brownish callus; (B) Saccharose: Greenish callus; (C) Mannitol: Brownish callus;

(D) Glucose: Greenish callus; (E) Maltose: Greenish callus; (F) Fructose: Greenish callus

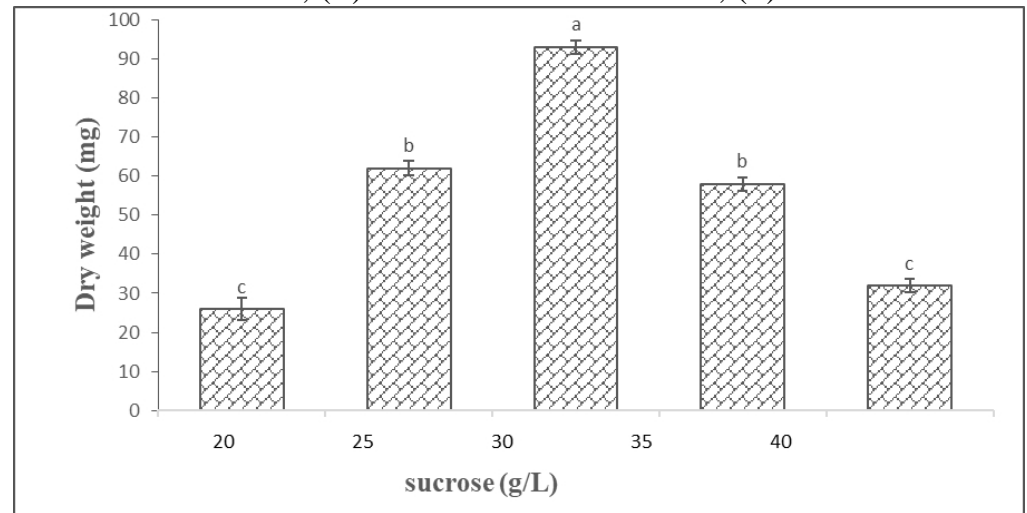

Figure 2. Effect of sucrose concentrations on callus proliferation

Taking into account the dry weight after six weeks of culture.

The tapes followed by the same letter are not significantly different (Newman Keuls test at $5 \%)$. 


\section{Discussion}

The study revealed that callogenesis in pineapple is significantly influenced by the carbohydrate nature. Since the in vitro photosynthesis is low or near zero (Pierik, 1987), sugars are very important ingredients. Their addition to the culture medium enables to bring the necessary energy for tissues development. According to Swankar et al. (1986), sugars influence cell proliferation and differentiation. However, all sugars have not the same effects on callogenesis. The results of this study showed that the fresh weight of calli is greater with glucose followed by mannitol and sucrose. These results confirm those of Kouakou (1996) and Zouzou et al. (1997), which showed that glucose in cotton produces friable, voluminous calli as compared to other sugars. Also, Najiba et al. (2008) reported that sucrose and mannitol in the olive tree produced the most developed nodular and compact calli. On the other hand, dry weight analysis revealed that sucrose induced the highest dry weight followed by galactose and glucose. These results could be explained by the fact that the glucose, which enabled us to obtain the highest fresh callus matter, would cause a strong entry of water into the cell while the sucrose would favor an increase of the medium osmotic pressure, therefore an entry of necessary minerals for the growth of calli. The results also showed that maltose and galactose have little beneficial effect on callus proliferation. These two sugars could not be assimilated by plant cells. However, the hydrolysis of maltose, in two molecules of glucose, should supply the plant cells with assimilable sugars. According to N'cho (2006), the unfavorable effect of maltose on cotton callus proliferation seems to indicate an absence or low amount of degradation enzymes, maltases, in pineapple calli. The positive effect of sucrose on pineapple calli dry weight is due to the fact that sucrose is composed of two monomers; fructose and glucose. Indeed, in an acid medium $(\mathrm{pH} 5.5)$, the sucrose would hydrolyze to, glucose and fructose to be assimilable. Therefore, there would be a complementary relation between these two sugars, which would together provide the necessary energy for the growth of calli. Moreover, this hydrolysis leads to an accumulation of glucose and fructose and consequently, to an increase in osmolarity that would induce an accumulation of reserves and mineral elements in the calli, which reflects the good development of these calli. In the culture medium, the osmotic role of sucrose has been reported in several studies (Tremblay and Tremblay, 1995; Taber et al., 1998; Find et al., 1998). According to Rugini (1995), the sucrose content of the culture medium affects the callus growth and subsequently the somatic embryogenesis through its interaction with growth regulators. Indeed, among the various carbon sources involved in the differentiation and osmotic adjustment, sucrose is the most frequently used in in vitro culture. In addition to its degradation for the synthesis of ATP and NADH via glycolysis and the Krebs cycle, sucrose is required for the biosynthesis of primary metabolites 
important for tissue growth and development (Sturm, 1999). Sucrose also participates in the synthesis of reserve substances such as starch and polypeptides (Sturm, 1999; Fernie et al., 2002). Moreover, the work of Zouzou et al. (1997) have also shown that glucose gives voluminous calli as compared to other sugars in cotton. These results corroborate those of the present study when only fresh calli weight is taken into account. However, glucose allowed us to obtain a much lower dry weight compared to sucrose. This means that glucose produces a small amount of matter. Thus, this work has shown that the calli proliferation in pineapples is highly correlated with the carbon source. These differences in effects observed by carbon source in this study would reflect specific affinities for a given type of sugar (Najiba et al., 2008). In addition, the content of the carbon source could influence the calli proliferation in pineapple. Indeed, the results of this study revealed that the sucrose content of $30 \mathrm{~g} / \mathrm{L}$ gave the most voluminous calli. These results were observed by Najiba et al. (2008) on the olive tree. Several authors have reported that the sugar concentration generally used for the induction and development of somatic embryos in several species is $20-30 \mathrm{~g} / \mathrm{L}$ (Han and $\mathrm{Xi}$, 1989; Rout et al., 1991). However, other authors have reported that high concentrations of sucrose may have adverse effects on embryo formation. This is the case of Geranium where concentrations 6; 9 or $12 \%$ inhibit the formation of somatic embryos (Gill et al., 1993). In other species, the induction and development of somatic embryos require a high rate of sucrose, like in the Asparagus (5\%) (Komura et al., 1990) and Chrysanthemum (12-18\%) (May and Trigiano, 1991). Indeed, according to the works of Buffard-Morel (1968) and those of Rabechault et al. (1974) high levels of sugars would promote the absorption of the mineral elements of the culture medium and consequently, lead to cell growth. These results show that the carbohydrate concentration effect depends on the plant species in the presence. In this study, sucrose at 30 $\mathrm{g} / \mathrm{L}$ was the most successful in the proliferation of calli. The dose effect of sucrose therefore has a great influence on the development of calli in pineapples.

\section{Conclusion}

The results of this study based on the influence of carbohydrates on the proliferation of calli in pineapple made it possible to identify sucrose as the preferred carbon source for callus proliferation enable us to obtain a large quantity of dry matter. On the contrary, glucose gives a much higher fresh weight. Comparison of sucrose levels showed that the $30 \mathrm{~g} / \mathrm{L}$ concentration improves callus proliferation in pineapple. Commonly used in in vitro culture, the concentration of $30 \mathrm{~g} / \mathrm{L}$ remains optimal for the proliferation of calli in pineapple. In view of these results, we can say that the proliferation of calli in pineapple (Ananas comosus var. Smooth Cayenne) depends on the nature and 
content of the carbon source. Galactose and maltose were less favorable to proliferation.

\section{References:}

1. Adomon S. (2007). Une filière aux abois, in Quot. Int. Group. Olym (Ed.), Côte d'Ivoire, Abidjan. 12p.

2. Akbar M., Karmakar B., \& Roy S. (2003). Callus Induction and Highfrequency Plant Regeneration of Pineapple (Ananas comosus (L.) Merr.). Plant Cell Tiss. Cult. 13 (2): 109-116.

3. Anonymous 1 (2008). Agriculture de la Côte d'ivoire. http://www.educarriere.net April $23^{\text {rd }} 2017$.

4. Anonymous 2 (2015). Ministère français de l'agriculture, de l'agroalimentaire et de la forêt: les politiques agricoles à travers le monde: quelques exemples. http://agriculture.gouv.fr/sites/minagri/files/1506-ci-resinter-fi-coteivoire.pdf. May $26^{\text {th }} 2015$.

5. Be L., \& Debergh P. (2006). Potential low cost microprpagation of pineapple (Ananas comosus). Sout. Afr. J. Bot., 72: 191-194.

6. Buffard-Morel J. (1968). Recherches sur la culture in vitro des embryons de palmier à huile. v. effets du glucose, du lévulose, du maltose et du saccharose. Oléagineux., 23 (12): 707-711.

7. Danso K., Aye K., Amiteye S., \& Amoatey H. (2008). Effect of 6Benzylaminopurine and 3-Naphthalene Acetic Acid on in vitro production of MD2 Pineapple planting materials. Worl. Appl. Sci. J., 3 (4): 614-619.

8. Fernie R., Willmitzer L., \& Trethewey R. (2002). Sucrose to starch: a transition in molecular plant physiology. Tren. Pl. Sci., 7: 35-41.

9. Find J., Nørgaard J., \& Krogstrup P. (1998). Growth Parameters, nutrient uptake and maturation capacity of two cell-lines of Norway spruce (Piceaabies) in suspension culture. J. Plant Physiol., 152: 510517.

10. Firoozabady E., \& Gutterson N. (2003). Cost-effective in vitro propagation methods for pineapple. Plant Cell Rep. 21: 844-850.

11. Gill G., Gerrath J., \& Saxena P. (1993). High frequency direct somatic embryogenesis in thin layer cultures of hybrid seed geranium (Pelargoniumx hortorum). Can. J. Bot. 71: 408-413.

12. Han H., \& Xi T. (1989). Rapid propagation of lettuce by embryos. Plant Physiol. Commun., 2: 17-20.

13. Ika R., \& Ika M. (1989). In vitro culture of Pineapple organogenesis and somatic embryogenesis: Its utilization and prospect. Bulet. Agrobio., 2003; 6 (1): 34-40.

14. 7Komura H., Chokyu S., \& Ikeda Y. (1990). Micropropagation of 
asparagus through somatic embryogenesis. 1. Somatic embryogenesis and plant regeneration from seedlings. Bull. Hiroshima Prefect. Agric. Exp. Stn. 53: 43-50.

15. Kouakou T. (1996). Effets composition et régime hormonal sur la callogenèse du cotonnier (Gossypium hirsutum L. cv. ISA $205 \mathrm{~N}$ ). Mémoire DEA physiologie végétale, option : Agrophysiologie, UFR Biosciences, Université de Cocody (Abidjan), 32p.

16. May R., \& Trigiano R. (1991). Somatic embryogenesis and plant regeneration from leaves of dendranthema grandiflora. J. Am. Soc. Hortic. Sci. 116 (2): 366-371.

17. MINAGRI. L'ananas. http://minagril.weblogy.net/. October $15^{\text {th }} 2013$.

18. Murashige T., \& Skoog F. (1962). A revised medium for rapid growth and bioassays with tobacco tissues culture. Physiol. Plant. 15: 473497.

19. N'cho X. (2006). Callogenèse chez le cotonnier (Gossypium hirsutum L.): effets cultivar, nature et teneur en source de carbone. Mémoire DEA physiologie végétale, option: Agrophysiologie, UFR biosciences, Université de Cocody (Abidjan), 36.

20. Najiba B., Dou E., \& Abdelhadi A. (2008). Effet du sucre sur l'embryogenèse somatique de l'olivier (Olea europaea L.) cv. «Picholine marocaine» Biotechnol. Agron. Soc. Environ.12 (3): 245250.

21. Nouza M. (2011). Business agricole : L'ananas rapporte 17 millions à l'hectare. Le Journal de L'économie http://news.abidjan.net/h/415980.html. Consulted on August $31^{\text {st }} 2016$.

22. OCAB. (2000). Organisation Centrale des producteurs exportateurs d'Ananas et de Bananes. Rapport annuel, document OCAB, Abidjan, 32p.

23. Pierik R. (1987). Commercial micropropagation in western Europe and Israel. in debergh p.c., zimmermanr.h. micropropagation technology application. dordretch, the netherlands: Kluw. Acad. Publ., 115-165.

24. Rabechault H., Buffard-Morel J., \& Vacheron C. (1974). Recherches sur la culture in vitro des embryons de palmier à huile: effets de la pression osmotique sur la croissance et le développement et sur l'absorption des sucres. Oléagineux, 29 (12): 351-356.

25. Rout G., Debata B., \& Das P. (1991). Somatic embryogenesis in callus cultures of Rosa hybrida L. cv. 'Landora'. Plant Cell Tissue Organ Cult. 27 (1), 65-69.

26. Rugini E. (1995). Somatic embryogenesis in olive (Olea europaea L.) In: Jain S., Gupta P. \& Newton R., eds. Somatic embryogenesis in woody plants. 2. Dordrecht, The Netherlands: Kluw. Acad. Publ., 171- 
189.

27. Saadi A. (1991). Régénération des plantes de pois (Pisum sativum L) par embryogenèse somatique. Thèse de doctorat. Paris Grignon. 162p.

28. Sturm A. (1999). Invertases primary structures, functions, and roles in plant development and sucrose partitioning. Plant Physiol., 121: 1-7.

29. Swankar P., Bohra S., \& Chandra N. (1986). Biochemical changes during growth and differentiation of the callus of Solanum surattense. J. Plant Physiol. 75-81.

30. Taber R., Zhang C., \& Hu W. (1998). Kinetics of Douglas-fir (Pseudotsuga menziesii) somatic embryo development. Can. J. Bot., 76: 863-871.

31. Tanoh R.. (2008). Ananas-La misère des planteurs, inQuot. Nord-Sud Group. Olym (Ed.), Côte d'Ivoire, Abidjan, 12p.

32. Tremblay L., \& Tremblay F. (1995). Maturation of black spruce somatic embryos: Sucrose hydrolysis and resulting osmotic pressure of the medium. Plant Cell, Tissue and Organ Cult., 42: 39-46.

33. Unnikrishnan S., Mehta A., \& Bhatt P. (1990). Abscissic acid induced high frequency embryogenesis from sapindustri foliatus leaves. Act. Hortic. 280: 89-94.

34. Walker D., \& Parrott W. (2001). Effect of polyethylene glycol and sugar alcohols on soybean somatic embryo germination and conversion. Plant Cell, Tissue and Organ Cul., 64: 55-62.

35. Yapo E, Tanoh K., Mongomaké K., Kouadio J, Kouamé P., \& Merillon J. (2011). La régénération de l'ananas (Ananas comosus L.) par embryogenèse somatique végétale. J. Bioch Plant Biotechnol. 20 (2): 196-204.

36. Zouzou M., Kouakou T., Koné M, Peeters M., \& Swennen R. (1997). Callogenèse chez le cotonnier cultive en Côte d'ivoire : Effets position explant hypocotyle, variete, source de carbone et régime hormonal. Afr. CropSci. Conf. Proc. 3: 1489- 1494.

37. Zryd J. (1988). Culture de cellules, tissus et organes végétaux. Ed. Press. Polytechn. Romandes Suisse. 308p. 